DOI https://doi.org/10.36059/978-966-397-237-4-6

Назарко А. T.,

кандидат юридичних наук,

доцент кафедри конституційного права

Національного університету «Одеська юридична академія»,

м. Одеса

\title{
ПРАВО НА УЧАСТЬ У МІСЦЕВОМУ САМОВРЯДУВАННІ: ТЕОРІЯ І ПРАКТИКА РЕАЛІЗАЦІЇ В УМОВАХ СПЕЦІАЛЬНИХ ПРАВОВИХ РЕЖИМІВ
}

\begin{abstract}
Анотація. Стаття присвячена дослідженню правового регулювання та реалізації права на участь у місцевому самоврядуванні в умовах спеціальних правових режимів в Україні. З'ясовано співвідношення права на участь у місцевому самоврядуванні із правом на місцеве самоврядування, проаналізовано основні напрями його реалізації. Розкрито питання співвідношення понять права на місцеве самоврядування $i$ права членів територіальних громад на участь у місцевому самоврядуванні, охарактеризовано сучасний стан вітчизняного законодавства щодо регулювання форм участі громадян у місцевому самоврядуванні в умовах запровадження карантину в Україні.

Право на участь у місцевому самоврядуванні розкривається за суттю, структурою та змістом, визначено систему форм реалізації цього права, їх властивостей та особливостей, проведено їх класифікацію. Надано пропозиціі щодо вдосконалення наявних форм реалізації права на участь у місцевому самоврядуванні, їх пристосування до умов запровадження карантинних заходів в Украӥні та можливого введення надзвичайного стану. Проаналізовано деякі нові інструменти та механізми участі членів територіальної громади у вирішенні питань місцевого значення (електронні петиції, робота консультативно-дорадчих органів), що спрямовані на підвищення активності місцевого населення у вирішенні питань місцевого значення.
\end{abstract}

\section{Вступ}

Взаємини людини із публічною владою мають не тільки багатовекторні «горизонтальні» характеристики, які випливають із множинності сфер соціального життя, але це одночасно й 
ієрархічні («вертикальні») лінії виміру положення особистості на різних рівнях її взаємин з публічною владою, як з державною, так і з публічно-самоврядною. Заохочення місцевого населення до вирішення питань місцевого значення та ефективного використання форм безпосередньої та представницької демократії $\epsilon$ ключовими завданнями модернізації місцевого самоврядування в Україні. В умовах децентралізації публічної влади в Україні значним чином підвищується інтерес до вивчення та узагальнення практики залучення громадян до вироблення та здійснення місцевої політики, адже досвід застосування різноманітних засобів участі членів територіальної громади у місцевому самоврядуванні не забезпечує належного результату урозвитку партнерських відносин між органами і посадовими особами місцевого самоврядування та жителями.

Теоретичні засади інституту місцевого самоврядування досить грунтовно розкрито у працях таких українських учених, як: О.В. Батанов, П.М. Любченко, О.Ю. Лялюк, М.П. Орзіх, В.Ф. Погорілко, С.Г. Серьогіна, К.Є. Соляннік, Ю.М. Тодика, В.Л. Федоренко та ін. Окремим питанням конституційно-правового регулювання участі територіальної громади у вирішенні питань місцевого значення присвячено дослідження багатьох вітчизняних науковців: Ю.Ю. Бальція, О.М. Бориславської, О.Д. Лазор, Н.В. Мішиної, Х.В. Приходько, С.Ю. Русанової, Б.А. Руснак та ін. Особливості використання окремих форм безпосередньої та представницької демократії у місцевому самоврядуванні вивчалися в працях В.М. Кампо, Р.М. Максакової, К.М. Москальчук, О.С. Орловського, Г.В. Падалка, Т.В. Стешенко та ін. Окремим досліджуваним у статті питанням було присвячено також і низку дисертаційних досліджень: П.А. Ткачука «Участь громадян України в місцевому самоврядуванні» (м. Київ, 2003 р.) і Р.Т. Чернеги «Право громадян на участь у місцевому самоврядуванні України: стан та шляхи вдосконалення» (м. Київ, 2007 р.), Л.О. Казакової «Конституційне право на місцеве самоврядування серед інших прав та свобод людини і громадянина в Україні» (Ужгород, 2018 р.), Ю.Ю. Молчанової «Муніципальне регулювання здійснення членами територіальної громади права на участь у місцевому самоврядуванні» (Харків, 2019 р.).

Право на участь у місцевому самоврядуванні як предмет дослідження вчених-конституціоналістів привертає значну увагу, адже досі залишаються невирішеними низка теоретичних та 
прикладних питань щодо визначення його поняття, змісту, форм реалізації, співвідношення з іншими конституційними правами людини і громадянина. Разом з тим нині існують проблеми реалізації права на участь у місцевому самоврядуванні членами територіальних громад, які зумовлені введенням особливого правового режиму на території України, спрямованого на запобігання виникненню і поширенню коронавірусної хвороби (COVID-19), а також викликаних як недостатнім рівнем професіоналізму муніципальних службовців і пануванням їхніх бажань, так і вадами і прогалинами чинного законодавства.

Виходячи з вищенаведеного, метою статті $\epsilon$ формулювання та визначення основних напрямів підвищення ефективності правових механізмів залучення громадян до місцевого самоврядування та становлення локальної демократії в Україні на основі аналізу нормативного закріплення та реалізації основних форм здійснення права на участь у місцевому самоврядуванні, зокрема, в умовах спеціальних правових режимів.

\section{1. Право на участь у місцевому самоврядуванні: юридична природа та зміст}

Великого значення у сучасних умовах розвитку громадянського суспільства та правової держави в Україні набуває належне забезпечення та реалізація конституційного статусу особистості, одним з основних складників якого $\epsilon$ право на участь у місцевому самоврядуванні.

Муніципальні права особи як складник нормативно-правового інституту місцевого самоврядування одночасно $\epsilon$ важливим інститутом муніципальної демократії, закріплений в Україні шляхом конституційного визнання та гарантування місцевого самоврядування (ст. 7). Сучасна теорія і практика конституціоналізму визнає існування прав і свобод людини і громадянина, які можуть бути реалізовані лише колективно, хоча цьому завжди сприяє можливість здійснення певних індивідуальних прав $[23$, c. 125]. Співвідношення цих прав полягає в тому, що індивідуальне право може здійснюватися колективно (наприклад, право на оскарження неправомірних дій або актів, право на отримання інформації про діяльність органів місцевого самоврядування та ін.), тоді як колективне право (участь у місцевих референдумах та виборах, право створення органів самоорганізації населення та ін.) не може бути реалізоване індивідуально. Можна 
погодитися з думкою деяких учених про існування двох аспектів теоретичної проблеми права на місцеве самоврядування, які пов'язані 3 індивідуальним і колективним началами у разі визначення природи цього права [3, с. 67].

Колективне право на місцеве самоврядування випливає з положень ч. 1 ст. 140 Конституції України, яка визначає суб'єктом колективного права територіальну громаду, разом із тим ч. 1. ст. 3 Закону України «Про місцеве самоврядування в Україні» містить положення щодо реалізації громадянами України права на участь у місцевому самоврядуванні за належністю до відповідних територіальних громад, що об'єктивно передбачає індивідуальне право громадянина. Вказане синтезоване формулювання має ключовий характер для визначення правової природи права на участь у місцевому самоврядуванні, оскільки поєднує індивідуальне право громадянина із колективним правом територіальної громади на місцеве самоврядування.

Особливе місце у системі сучасного наукового знання та методології юриспруденції належить інституціональній теорії, постулатами якої $є$ використання міждисциплінарного аналізу та виокремлення соціального інституту як основного елемента теорії і практики [13]. 3 позицій інституціонального підходу до аналізу прав і свобод людини і громадянина слід визнати існування конституційних прав і свобод, які за формою та змістом $€$ комплексними інститутами. Таким, виходячи з аналізу практики Конституційного Суду України, $€$ конституційне право на звернення, закріплене ст. 40 Конституції України, оскільки, поперше, його утворюють різні за природою i призначенням юридичні засоби, метою яких $є$ забезпечення реалізації кожною людиною своїх прав і свобод, а також їх відстоювання, захист та відновлення у разі порушення [42]; по-друге, особливості порядку звернення із заявою та скаргою та їх розгляду у відповідних сферах правовідносин визначаються законами України (стаття 12 Закону України «Про звернення громадян» [34]).

Застосування інституціонального підходу дозволяє розглядати право на участь у місцевому самоврядуванні як самостійний комплексний правовий інститут. За змістом цей інститут охоплює юридично визначені форми організації та регулювання суспільного життя на місцевому рівні, що забезпечують виконання життєво важливих для суспільства функцій, та реалізується через систему інституцій місцевої демократії, яка «містить низку 
органічно взаємопов'язаних елементів, що діють як комплексний механізм, основним завданням якого $\epsilon$ створення необхідних передумов для реалізації права громадян на участь у місцевому самоврядуванні» [45, с. 14]. 3 одного боку, цей інститут $\epsilon$ складовою частиною інституту вищого рівня - місцевого самоврядування, 3 іншого - складається із субінститутів, які охоплюють норми, що визначають основні форми реалізації права на участь у місцевому самоврядуванні. Структуру такого інституту становлять: сукупність норм, що визначають основні форми реалізації права на участь у місцевому самоврядуванні, система уповноважених суб'єктів, зокрема територіальна громада, члени територіальних громад, органи місцевого самоврядування, органи самоорганізації тощо.

Об'єктом права на участь у місцевому самоврядуванні $\epsilon$ доступ громадян України - членів територіальних громад до участі у місцевому самоврядуванні. У цьому контексті, як справедливо наголошує О.С. Шугріна, варто відрізняти право на місцеве самоврядування від права брати участь у місцевому самоврядуванні $[49$, с. 33]. Так, Л.О. Казакова вважає, що право на місцеве самоврядування варто розуміти як надане конституційними нормами та чинним законодавством право особи на самостійне вирішення питань місцевого значення з використанням передбачених законодавством та актами місцевого самоврядування форм участі в публічній діяльності, що включають право вимоги надання такого права та можливості його реалізації в межах муніципального утворення [15, с. 4]. При цьому елементами названого права є: право на участь у місцевому самоврядуванні як можливість особи з використанням усіх форм місцевих ініціатив впливати на вироблення політики у сфері вирішення локальних питань та на формування утворень, наділених владними повноваженнями відповідно до територіальної приналежності та право на здійснення місцевого самоврядування як здатність наділеної владними повноваженнями особи, що зумовлена ії територіальною приналежністю, на індивідуальну або колективну діяльність, результатом якої $\epsilon$ вироблення правових норм локального характеру 3 метою вирішення питань, пов'язаних із забезпеченням функціонування територіальної громади. Привертає увагу звуження змісту права на місцеве самоврядування, адже воно передбачає можливість лише здійснення місцевого самоврядування і лише особою, 
наділеною владними повноваженнями без належного розмежування права на здійснення місцевого самоврядування від права на участь у місцевому самоврядуванні.

У літературі трапляється думка, що право на участь у місцевому самоврядуванні $\epsilon$ додатковим до такого основного права, як право брати участь в управлінні державними справами. Так, досліджуючи право на місцеве самоврядування, Л.О. Казакова формулює пропозиції щодо внесення змін у статтю 38 Конституції України, мотивуючи тим, що конституційне право громадян на управління державними справами (частина 1 статті 38 Конституції України) як самостійний публічний інститут $є$ окремим правом громадян, яке не входить до права на місцеве самоврядування. Разом із тим не викликає дискусій те, що право брати участь у місцевому самоврядуванні $\epsilon$ комплексним правом, що конкретизується через низку додаткових індивідуальних та колективних прав громадян України [15, с. 11]. На думку П.А. Ткачука, серед прав і свобод громадян у системі місцевого самоврядування можна виокремлювати: 1) права на участь, які включають право на участь в управлінні місцевими справами, право на участь у місцевих виборах, право брати участь у місцевому референдумі, право рівного доступу до служби в органах місцевого самоврядування; 2) інтегративні права - звернення до органів місцевого самоврядування, свободи об'єднань, свободи слова та право на інформацію, право на місцеву ініціативу, право мирних зборів, мітингів, походів, демонстрацій [43, с. 8].

Проблемним залишається питання щодо визначення кола суб'єктів права на участь у місцевому самоврядуванні. Дихотомічний характер суб'єктного складу права на участь у місцевому самоврядуванні випливає із суперечливих положень Конституції України (ст. 140) та Закону України «Про місцеве самоврядування в Україні» (ст. 2, 3), згідно з якими місцеве самоврядування одночасно визнається правом територіальної громади (жителів села чи добровільного об’єднання у сільську громаду жителів кількох сіл, селища та міста) та правом громадян України брати участь у місцевому самоврядуванні за їх належністю до відповідних громад.

У вітчизняній юридичній науці уявлення про право на участь у місцевому самоврядуванні детерміноване розумінням природи самоврядування як первинного права територіальної громади на вирішення питань місцевого значення. Водночас аналіз 
зарубіжного досвіду конституційного регулювання муніципальноправових відносин свідчить, що в більшості 3 них громада унормовується як первинна ланка місцевого самоврядування та являє собою публічно-правову територіальну корпорацію, яка має певну свободу дій щодо забезпечення потреб жителів за принципом негативного регламентування компетенції [7, с. 330], що створює умови для реалізації місцевими мешканцями права на самоврядування не тільки опосередковано через діяльність органів місцевого самоврядування, але й індивідуально разом 3 іншими особами, які мають тісні зв'язки з громадою. Так, у Чехії гарантується принцип місцевого самоврядування територіальних одиниць (ст. 8 Конституції Чеської Республіки) [19], що передбачає, зокрема, наявність власної компетенції місцевого самоврядування як самостійної форми публічної влади (ст. 101, п.п. 1, 2; ст. 104 Конституції Чеської Республіки), визначення основним носієм права на місцеве самоврядування територіальних співтовариств громадян (ст. 100, п. 1, ст. 101 п. 3 Конституції Чеської Республіки), закріплення як територіальної основи місцевого самоврядування громади (ст. 99 Конституції Чеської Республіки), яка розглядається як «публічна корпорація, яка може мати власне майно і господарювати згідно зі своїм бюджетом». Отже, корпорація в наведених правових актах відображає наявність особливого суб'єкта права, який різниться від носія громад загалом, а членство в такій корпорації не залежить від волі iї учасників. Правове визначення самоврядування набуває ознак особливої організаційної форми піклування всього суспільства про найбільш важливі питання життєдіяльності об'єднань громадян, які проживають на території громади [47, с. 178-179].

Територіальна громада $\epsilon$ складною формою суспільної організації, сукупністю місцевих жителів, об'єднаних у межах певної території, що становить певну нормативно-правову модель самоорганізації населення з управлінськими структурами, здатна реалізувати і захищати місцеві публічні та приватні інтереси $[48$, c. 12]. У конституційному законодавстві багатьох європейських країн під громадою розуміється низова адміністративнотериторіальна одиниця устрою держави (наприклад, Закон про самоврядування гмін у Польщі визнає її основною одиницею територіального самоврядування, яку слід розуміти як співтовариство самоврядування, так і відповідну територію (ст. 1) [30]. Разом із тим у більшості країн світу первинними суб'єктами 
місцевого самоврядування визнаються фізичні особи, що об'єднані спільними інтересами та територією. Вказані особи мають можливість у межах правових норм здійснювати регламентування та адміністрування публічних справ, під власну відповідальність та в інтересах місцевих жителів, що передбачає необхідність створення відповідної інституційної структури у вигляді органів місцевого самоврядування [25, с. 78].

За таких умов участь населення у здійсненні місцевого самоврядування полягає, по-перше, у прямій участі в організації та діяльності муніципалітетів як через заходи безпосередньої демократії (місцеві вибори), а також особистій участі в їх роботі, по-друге, у опосередкованій участі жителів в управлінні місцевими справами у різних формах (громадська ініціатива, загальні збори, опитування, петиції тощо) [14]. Теоретично такі механізми участі у місцевому самоврядуванні дають людям рівні шанси бути залученими до рішень, які впливають на їхнє життя та добробут, а також $\epsilon$ важливим практичним способом для осіб, що об'єднані територією i інтересами, навчитися працювати разом та оцінювати співпрацю як метод вирішення проблем [1].

Суб'єктами права на участь у місцевому самоврядуванні $\epsilon$ переважно громадяни України, які для реалізації муніципальних прав повинні відповідати низці недискримінаційних цензів: віковому, осілості і т. ін. Доволі широкий зміст права на участь у місцевому самоврядуванні детермінує неможливість точного визначення кола суб'єктів, наділених правами на вирішення місцевих питань. Закон України «Про місцеве самоврядування в Україні» одночасно містить два поняття, що визначають належність особи до територіальної громади: 1) жителі територіальної громади, 2) члени територіальної громади. Привертають увагу декілька питань. По-перше, закон не містить чіткого визначення та співвідношення термінів, а критерієм належності особи до громади $є$ тільки постійне проживання на їі території, яке законодавством так само не конкретизоване. По-друге, наголошення на необхідності мати зареєстроване місце проживання для підтвердження проживання особи в територіальній громаді на практиці призводить до змішування понять «місце проживання» та «зареєстроване місце проживання», які використовуються як синоніми. По-третє, правова невизначеність призводить до того, що за умов зумовленості можливості реалізації права на участь у місцевому самоврядуванні 
за місцем проживання особи (як, наприклад, у випадку з деякими механізмами місцевої демократії) воно автоматично розуміється як зареєстроване місце проживання. Внаслідок цієї ситуації понад 8,3 млн осіб в Україні потенційно можуть зазнавати дискримінації щодо права на безпосередню участь у місцевому самоврядуванні, водночас близько 6,8 млн - це особи, що мешкають не за зареєстрованим місцем проживання, 1,4 млн - внутрішні переселенці, 114 тис. - іноземці, які тимчасово проживають в Україні, що становить більш ніж 20\% нашої держави [17]. 3 метою подолання цих негативних наслідків деякі органи місцевого самоврядування намагаються у статутах територіальних громад закріпити категорії осіб, які належать до жителів/членів територіальних громад, всупереч нормам закону про місцеве самоврядування, попри те, що навіть визначення осіб, які мають у громаді зареєстроване місце проживання, не дозволить охопити всієї сукупності жителів відповідних територіальних громад.

Аналіз положень чинного законодавства свідчить, що право на участь у місцевому самоврядуванні має значний ступінь диференціації за критеріями для набуття та реалізації відповідних прав. Так, ст. 1 Закону «Про місцеве самоврядування в Україні» визначає загальні збори як зібрання всіх чи частини жителів села (сіл), селища, міста для вирішення питань місцевого значення [36], водночас ст. 8 цього ж Закону вживає термін «загальні збори громадян», що кардинально відрізняється від попередньої норми. За таких умов житель громади, який є особою без громадянства, відповідно до ст. 1 може брати участь у загальних зборах, а відповідно до ст. 8 не зможе, адже не є «громадянином». Подібні питання виникають, зокрема, і щодо права на участь у громадських слуханнях, права на місцеві ініціативи можуть мати лише члени територіальної громади (члени територіальної громади - ст. 9, 13 Закону України «Про місцеве самоврядування в Україні»), органів самоорганізації населення, які, з одного боку, можуть створюватися жителями, які на законних підставах проживають на території села, селища, міста або їх частин [37], з іншого - такі жителі можуть проживати в громаді як постійно, так і тимчасово, що на практиці означає більш широке коло суб'єктів створення органів самоорганізації населення порівняно із колом жителів/членів громади.

Вирішення проблемної ситуації бачиться у напрямі запровадження внесення змін до законодавства, по-перше, щодо дозволу реєстрації декількох місць проживання, одного як 
основного, інших як додаткових; по-друге, уніфікації термінології профільного законодавства 3 метою уникнення різночитань щодо понять «член» та «житель» територіальної громади на користь останнього. Жителі повинні визначатися як сукупність усіх громадян України, іноземців та осіб без громадянства, які на законних підставах проживають у межах територіальної громади; по-третє, диференціювати форми місцевої демократії залежно від надання можливості користуватися ними лише жителям громади (загальні збори, громадські слухання, місцеві ініціативи, органи самоорганізації населення), або більш широкому колу суб'єктів, які не є жителями громади, але можуть залучатися до деяких із цих форм локальної демократії з правом дорадчого голосу, але із гарантуванням їх на рівні закону; почетверте, всі жителі, незалежно від реєстрації в громаді, мають отримати рівні права, за винятком права на участь у виборах та місцевих референдумах, із пріоритетним правом голосу у громаді, яка є основним місцем проживання.

Проєкт закону про місцеве самоврядування [36], не ставлячи під сумнів правосуб'єктність жителів територіальної громади, проводить більш чітку диференціацію індивідуальних суб'єктів права на участь у місцевому самоврядуванні, якими є: по-перше, громадяни України, які проживають на території громади постійно та мають усі права на участь у місцевому самоврядуванні, включно з правом на вибори і референдум, по-друге, люди, які володіють нерухомим майном у громаді, або які сплачують податки на майно на території громади та мають право на консультативні форми участі в прийнятті рішень органами місцевого самоврядування, зокрема публічні консультації, місцеві ініціативи тощо. Запропонований підхід загалом відповідає практиці багатьох європейських країн, коли люди, які дотичні до громади, мають власні інтереси і право на те, щоб вони були враховані у разі здійснення публічної влади у громаді.

Одним із основних завдань муніципальної реформи в Україні проголошено створення системи безпосередньої муніципальної демократії, яка різними авторами розглядається як демократія участі або партисипативна демократія [6, с. 22], під якою розуміється процес залучення широкого кола суб'єктів, зокрема фізичних осіб та інститутів громадянського суспільства, до процесу формування та реалізації політики на місцевому рівні публічної влади [2; 10; 24; 27]. Вихідними позиціями щодо 
розвитку концепції партисипативної демократії у Західній Європі було неконкурентне поєднання прямої та представницької форм народовладдя [9, с. 14], що призводило до недосконалості системи представництва та нереалізовуваності прямої демократії. До форм партисипативної демократії у літературі відносять: зустрічі громадян 3 представниками влади, соціальне замовлення, громадські (експертні ради), громадські обговорення, громадські експертизи, відкликання депутатів місцевих рад, дострокове припинення повноважень голів представницьких органів громад, рекламні, агітаційні та «лобістські» кампанії, органи самоорганізації населення тощо. Цей доктринальний підхід загалом кореспондує положенням ст. 69 Конституції України щодо наявності інших форм безпосередньої демократії.

Аналіз чинного законодавства та практики його застосування дозволяє виокремити такі індивідуальні права, що становлять зміст права на участь у місцевому самоврядуванні, як: 1) активне та пасивне виборче право на місцевих виборах; 2) право ініціювати та брати участь у місцевих референдумах; 3) право на отримання повної та достовірної інформації про діяльність органів місцевого самоврядування; 4) право на звернення до органів місцевого самоврядування та їх посадових осіб; 5) право на доступ до служби в органах місцевого самоврядування; 6) на оскарження у суді рішень, дій чи бездіяльності органів місцевого самоврядування, посадових осіб тощо. Серед прав, які можна реалізувати лише колективно (колективних прав), слід виокремити дві групи прав: 1) права спільнот (право на здійснення територіальною громадою публічної влади, органів самоорганізації населення, ініціативних груп жителів); 2) конституційні політичні права (право збиратися мирно, без зброї і проводити збори, мітинги, походи і демонстрації тощо).

Важливим зауваженням щодо наведеної структурної характеристики змісту права на участь у місцевому самоврядуванні $\epsilon$ те, що уявлення про юридичну природу права на участь у місцевому самоврядуванні сформувалося на грунті конституційноправового розуміння природи місцевого самоврядування як первинного права територіальної громади на вирішення питань місцевого значення. Інший концептуальний підхід склався убільшості демократичних зарубіжних країн, де первинним суб'єктом місцевого самоврядування визначаються люди, що об'єднані спільними інтересами і територією. За таких умов виникає можливість регламентувати й керувати місцевими публічними 
справами під власну відповідальність 3 метою задоволення інтересів місцевих жителів у межах правових приписів. Найбільш ефективною формою забезпечення реалізації інтересів місцевих жителів за таких умов $\epsilon$ створення організаційно-правових інститутів, якими $\epsilon$ органи місцевого самоврядування. Отже, участь жителів у здійсненні місцевого самоврядування набуває дихотомічної природи: з одного боку, це пряма або безпосередня участь у формуванні, організації та діяльності муніципалітетів шляхом виборів місцевих органів публічної влади, муніципальної служби, створення консультативних, експертних, контрольних установ та особиста участь в їх роботі, з іншого боку, опосередкована участь жителів муніципалітетів в управлінні місцевими справами у різних формах участі (громадська ініціатива, громадські слухання, загальні збори, громадські опитування, петиції тощо) [14].

Із оголошенням у січні 2020 року Всесвітньою організацією охорони здоров'я (ВОО3) надзвичайного стану в галузі охорони здоров'я міжнародного рівня Україна, як і більшість країн світу, була вимушена запровадити заходи щодо стримування спалаху коронавірусної хвороби (COVID-19). Для уникнення поширення пандемії в Україні активно почали вживатися обмежувальні заходи відповідно до Указу Президента України від 13 березня 2020 року № 87 [38], постанови Кабінету Міністрів України від 11.03.2020 № 211 [32], Закону України «Про внесення змін до деяких законодавчих актів України, спрямованих на запобігання виникненню і поширенню коронавірусної хвороби (COVID-19) від 17 березня 2020 року № 530-IX» [28]. Встановлення карантину значним чином вплинуло на порядок здійснення багатьох прав i свобод людини і громадянина та, зокрема, на реалізацію права на участь у місцевому самоврядуванні. Не маючи на меті докладний аналіз конституційності, законності та доцільності заходів, які були введені з боку держави, слід усе ж таки зупинитися на деяких питаннях, пов'язаних із правовою їх оцінкою.

3 першого погляду, заборони, що запроваджені вказаними нормативно-правовими актами та рішеннями представницьких органів місцевого самоврядування, обмежують конституційні права і свободи, наприклад, свободу мирних зібрань, свободу пересування та інші. Разом із тим Конституцією України прямо не передбачено заборони обмеження цих прав за умов наявності відповідного закону, адже загальновизнаним стандартом для більшості конституційних прав та свобод щодо їх обмежень $€$ 
одночасна наявність таких критеріїв: по-перше, відповідне обмеження має бути встановлене законом, а по-друге, переслідувати легітимну мету. Цей підхід підтверджується і позицією Конституційного Суду України, який визначив сутність «обмеження конституційних прав і свобод людини і громадянина» в контексті частини першої статті 64 Конституції України у такий спосіб: 1) це «не передбачене конституційними нормами звуження обсягу прав і свобод» [40]; 2) «У традиційному розумінні діяльності визначальними поняттями змісту прав людини є умови i засоби, які становлять можливості людини, необхідні для задоволення потреб її існування та розвитку. Обсяг прав людини це їх сутнісна властивість, виражена кількісними показниками можливостей людини, які відображені відповідними правами, що не $\epsilon$ однорідним і загальним. Загальновизнаним $\epsilon$ правило, згідно з яким сутність змісту основного права в жодному разі не може бути порушена [41].

Переконливим аргументом на користь визнання обгрунтованості застосовування обмеження прав та свобод, які гарантовано Конвенцією про захист прав людини і основоположних свобод (далі-Конвенція), $є$ критерій необхідності збереження демократичності суспільства, який $є$ визначальним для Європейського Суду 3 прав людини (далі - ЄСПЛ) у разі вирішення питань пропорційності обмеження конкретного права людини. Виходячи 3 положень Конституції України (ст. 3, 27, 34), навряд чи можна сумніватися у наявності легітимної мети щодо обмежень прав і свобод людини, оскільки людина, її життя, здоров'я й безпека - це, згідно з чинною Конституцією України, найвища соціальна цінність. Але при цьому, згідно з рекомендаціями $\mathrm{OOH}$ "Human rights at the time of COVID-19 - a Guidance Note", ці обмеження мають бути пропорційними, необхідними та недискримінаційними. У низці рішень ЄСПЛ вказується на позитивний обов'язок держави, тоді як невживання необхідних заходів, як правило, вважається порушенням позитивних зобов'язань, передбачених статтями 2 та 8 Конвенції (Фіногенов та інші проти Росії, № 18299/03, 20 грудня 2011 року [12]). ЄСПЛ, роз'яснюючи порядок застосування ст. 15 Конвенції, наголосив, що належна увага має бути приділена таким факторам, як: зміст прав, що порушено у зв'язку з відступом від позитивних зобов'язань, характеристика обставин, що призвели до виникнення надзвичайної ситуації, їі тривалість (Brannigan та McBride проти Сполученого Королівства, § 43 [8]); наскільки 
звичайне законодавство було достатнім, щоб подолати загрозу, спричинену суспільною небезпекою; чи є заходи дієвою реакцією на надзвичайну ситуацію; чи було використано заходи з тією метою, щодо якої вони були санкціоновані; чи передбачалися гарантії проти зловживань; національне право повинне розумно ясно визначати обсяг і спосіб реалізації відповідних повноважень, покладених на державні органи, аби гарантувати особам мінімальний рівень захисту, яким вони наділені у демократичному суспільстві відповідно до принципу верховенства права; чи додержано балансу інтересів індивідуального і громадського здоров'я, оскільки порушення фізичної недоторканості заявника можна вважати виправданим міркуваннями охорони здоров'я населення та необхідністю контролювати поширення інфекційного захворювання [21].

Таким чином, право на участь у місцевому самоврядуванні пов'язане зі спільними інтересами членів територіальних громад у різноманітних сферах суспільного життя, зумовлює формування окремого виду прав людини - муніципальних, які забезпечують кожному члену територіальної громади реальну можливість брати участь у вирішенні питань місцевого значення. Цим правам притаманна дихотомічна природа, з одного боку, вони мають конституційний рівень визнання, з іншого - будучи спрямованими на урегулювання відносин щодо самоорганізації населення, мають бланкетний характер, тобто потребують деталізації в нормативноправових актах загальнодержавного i локального рівня. Вітчизняна конституційно-правова модель регулювання місцевого самоврядування характеризується позитивним підходом у регламентуванні права на управління місцевими справами, що обмежує принцип самостійності у разі вирішення питань місцевого значення територіальними громадами безпосередньо або через органи місцевого самоврядування.

Проголошення коронавірусної хвороби на міжнародному рівні пандемією, яка несе загрозу та суспільну небезпеку, загалом може бути сприйняте як необхідний критерій у контексті ст. 15 Конвенції. Основними законами, які спрямовані на боротьбу з епідеміями, поширенням небезпечних вірусів та інфекцій, є: закони України «Про захист населення від інфекційних хвороб», «Про забезпечення санітарного та епідемічного благополуччя населення», Кодекс цивільного захисту України та Закон «Про правовий режим надзвичайного стану». Цими законами 
передбачено три спеціальні правові режими: 1) карантин (закони «Про захист населення від інфекційних хвороб», «Про забезпечення санітарного та епідемічного благополуччя населення»); 2) надзвичайна ситуація (Кодекс цивільного захисту України); 3) надзвичайний стан (закон «Про правовий режим надзвичайного стану»). Але проблеми визначення адекватності заходів та достатності національного законодавства в контексті обмеження прав на території України та виправданості меж втручання викликали численні дискусії у суспільстві. Мабуть, тому на території України було вибрано модель подолання суспільно небезпечних наслідків пандемії коронавірусної хвороби шляхом введення режиму карантину та надзвичайної ситуації, а не надзвичайного стану, оскільки не має чітко визначених меж як щодо прав, які можуть бути обмежені, так і щодо ступеня їх обмеження, та здебільшого має рекомендаційний характер.

\section{2. Форми реалізації права на участь у місцевому самоврядуванні в умовах спеціальних правових режимів: досвід і проблеми}

Досвід використання різних форм локальної демократії в умовах карантину виявив недосконалість матеріальних та процесуальнопроцедурних норм щодо реалізації суб'єктами права на участь у місцевому самоврядуванні [11]. Привертає увагу загальний висновок про неадаптованість різних форм і методів локальної демократії до потреб карантину у більшості територіальних громад. У проєкті Закону «Про місцеве самоврядування в Україні» [36] передбачено кілька форм участі жителів у прийнятті рішень органами місцевого самоврядування. Так, формами, які можуть ініціювати жителі громади, є: загальні збори, давно відома форма участі; місцеві ініціативи - жителі громади можуть розробити проєкт рішення ради чи виконавчого органу і подати його на розгляд; громадський бюджет - безпосередній розподіл частини коштів місцевого бюджету жителями територіальної громади; громадська експертиза - жителі можуть зробити експертизу діяльності виконавчого органу з якогось питання та подати їі на розгляд ради. $€$ також форми участі, які можуть ініціювати органи місцевого самоврядування: публічні консультації; консультативнодорадчі органи. Публічні консультації та громадські слухання також стають обов'язковими з широкого кола питань. Конкретні правила і процедури всіх цих форм участі повинні бути визначені у статуті територіальної громади. 
Одне з основних прав членів територіальних громад - право на отримання інформації в умовах карантину - має тенденцію до ускладнення реалізації, тоді як аналіз профільного законодавства свідчить, що обмеження прав і свобод людини не мають стосуватися права на доступ до публічної інформації, а законодавством передбачено низку гарантій щодо отримання відомостей про кількісні та якісні показники діяльності органів влади, стан реалізації протиепідемічних заходів тощо, оскільки згідно із законом задокументована у будь-який спосіб інформація стосовно розвитку пандемії, яка $\epsilon$ у володінні розпорядників, вважається публічною. Зрозуміло, що ця інформація може мати різний рівень доступу за умов дії презумпції відкритості публічної інформації, окрім випадків, встановлених законом (ч. 2 ст. 1 Закону України «Про доступ до публічної інформації» [31]). Такими можуть бути, зокрема, лікарська таємниця щодо конкретних людей та їхніх персональних/конфіденційних даних. Будь-яка інша інформація не має визнаватися «обмеженою» 3 огляду на рівень суспільної загрози. Таким чином, практично вся інформація, якою володіють суб'єкти публічної влади на місцях, щодо епідемії $\epsilon$ публічною 3 відкритим доступом. Це стосується і кількості спеціального медичного обладнання, медичних препаратів та вакцин, обсяг коштів місцевого та державного бюджету у розрізі їх витрати, кількість хворих та підозр на захворювання.

У контексті реалізації права на доступ до публічної інформації в умовах карантину законодавством передбачено надання відповіді не пізніше 48 годин з дня отримання запиту у разі, якщо запит на інформацію стосується інформації, необхідної, зокрема, для захисту життя чи свободи особи, стану довкілля, небезпечних природних явищ та інших надзвичайних подій, що загрожують безпеці громадян (ч. 2 ст. 20 Закону України «Про доступ до публічної інформації» [31]). Якщо звернутися до визначення найбільш ефективного способу подолання наслідків пандемії шляхом запровадження надзвичайного стану у сфері публічної інформації, слід підкреслити, що Закон України «Про правовий режим надзвичайного стану» в цьому разі не містить жодних спеціальних гарантій та загальних підстав для обмежень, за винятком особливих обставин, а саме масових заворушень, пов'язаних із виготовленням і розповсюдженням інформаційних матеріалів, що спрямовані на дестабілізацію правопорядку, введення спеціальних правил використання зв'язку, обміну 
інформацією через мережу Інтернет тощо. Але, як показано вище, за процедурними аспектами, підставами введення та способами забезпечення реалізації режим надзвичайного стану має більш жорсткий характер порівняно з карантином стосовно додержання прав і свобод людини і громадянина та може бути введений за умов значного підвищення рівня суспільної небезпеки.

Одним 3 напрямів реалізації права на інформацію в межах локальної демократії є відкритість роботи представницьких та виконавчих органів місцевого самоврядування, що передбачає вільний доступ до приміщень, у яких проходять сесії місцевих рад, та можливість висвітлення їхньої діяльності у засобах масової інформації. 3 початком карантину виникло багато проблем щодо реалізації цього права, зокрема, непоодинокі випадки встановлення різних обмежень, які, як правило, запроваджувалися в діяльності органів місцевого самоврядування на підставі розпоряджень міських, сільських та селищних голів. Так, шість міських рад заборонили громадянам відвідувати сесії: Київ, Краматорськ, Рівне, Херсон, Хмельницький і Львів. Крім того, три міста заборонили бути присутніми журналістам: Київ, Хмельницький та Львів, тоді як статтею 38 Закону «Про телебачення і радіомовлення» та статтею 26 Закону «Про друковані засоби масової інформації (пресу) в Україні» передбачено, що у разі пред'явлення посвідчення журналісти мають право перебувати в районах стихійного лиха і катастроф, у місцях аварій, масових безпорядків, на мітингах, зборах, демонстраціях та інших масових заходах, на територіях, де оголошено надзвичайний стан [20]. При цьому у Києві, Херсоні, Полтаві заборона була ухвалена одноосібно міськими головами, а у Львові - рішенням міської комісії з питань техногенно-екологічної безпеки і надзвичайних ситуацій, а у Хмельницькому з цього приводу взагалі не ухвалювалося жодних офіційних рішень. Негативним прикладом у цьому сенсі $\epsilon$ розпорядження голови Рівненської облради «Про заходи в Рівненській обласній раді 3 метою попередження виникнення гострої респіраторної хвороби, спричиненої коронавірусом COVID-19», ухвалене в березні 2020 року, у якому, зокрема, передбачалося: «Тимчасово обмежити допуск до адміністративних приміщень Рівненської обласної ради ... усіх осіб, крім депутатів Рівненської обласної ради, народних депутатів України, керівництва Рівненської обласної державної адміністрації, працівників виконавчого апарату обласної ради, працівників правоохоронних органів, осіб, які забезпечують 
громадський порядок (за погодженням з органами поліції), та доповідачів (за окремим списком)». Подібні рішення обгрунтовувалися із позицій необхідності додержання карантинних заходів 3 посиланням на надзвичайну ситуацію та полягали насамперед у забороні будь-кому, окрім депутатів, бути присутніми на пленарних засіданнях сесій. Тим самим фактично запроваджувався закритий для громадськості, засобів масової інформації та журналістів режим роботи депутатів, що створювало умови для непублічного та кулуарного вирішення деяких питань, які становлять суспільний інтерес і не стосуються безпосередньо проблем забезпечення громадського здоров'я. Єдиним винятком натепер $є$ проведення заходів у режимі відеоконференції, дистанційно, відповідно до п. 111 розділу 5 Закону України «Про місцеве самоврядування».

Досить часто обмеження, пов'язані із недопуском на засідання місцевих рад, стосувалися журналістів та представників 3МI (Запорізька міська рада, Рівненська обласна рада, Закарпатська обласна рада) [4]. Ці дії вводилися всупереч положенням чинного законодавства, оскільки журналіст має право відвідувати приміщення органів державної влади й відкриті заходи (ч. 2 ст. 25 Закону України «Про інформацію» [35]), використовувати технічні прилади для аудіо-, відеозапису (ч. 1 ст. 25 Закону України «Про інформацію» [35]), перебувати в місцях i на територіях, де оголошено карантин (ч. 4 ст. 25 Закону України «Про інформацію» [35]). Недопуск представників ЗМІ на відкриті заходи слід вважати перешкоджанням законній професійній діяльності журналіста, що має ознаки кримінального правопорушення, передбаченого статтею 171 Кримінального кодексу України [22].

Виходячи 3 фундаментального принципу організації та діяльності органів публічної влади в Україні, всі органи державної влади та місцевого самоврядування, їх посадові особи повинні діяти лише на підставі, в межах повноважень та у спосіб, що передбачені Конституцією та законами України (ч. 2 ст. 19). Порядок проведення сесій в аспекті їх відкритості закріплений уч. 17 ст. 46 Закону України «Про місцеве самоврядування», він передбачає, що сесії ради проводяться гласно із забезпеченням права кожного бути присутнім на них, крім випадків, передбачених законодавством, а порядок доступу до засідань визначається радою відповідно до закону. 3 цього випливає, що жодна посадова особа, в тому числі сільські, селищні, міські голови, не мають права привласнювати не притаманні їм повноваження. 
По-перше, у законі мають бути чітко визначені випадки, коли може бути обмежене право відповідного суб'єкта бути присутнім на сесії; по-друге, порядок доступу визначається відповідною місцевою радою, а не сільським, селищним, міським головою. Таким чином, голови можуть скликати сесію, але режим ії проведення (закритий або відкритий) має визначатися лише рішенням відповідної місцевої ради.

Основним нормативно-правовим актом, який має визначати порядок доступу на пленарні засідання сесії, $\epsilon$ регламенти місцевих рад, прийняття яких також $є$ їх виключною компетенцією (п. 1 ч. 1 ст. 26 Закону України «Про місцеве самоврядування»). Проведений аналіз змісту багатьох регламентів місцевих рад підтверджує, що практично всі вони закріплюють положення про прийняття рішення про проведення закритих пленарних засідань виключно самою місцевою радою, що цілком відповідає вимогам вищеназваного базового Закону у сфері місцевого самоврядування. Навіть якщо звернутися до Постанови Кабінету Міністрів України від 11 березня 2020 року № 211 «Про запобігання поширенню на території України коронавірусу COVID-19», можна переконатися, що обмежується «проведення всіх масових заходів, у яких бере участь понад 200 осіб, крім заходів, необхідних для забезпечення роботи органів державної влади та органів місцевого самоврядування». Як відомо, кількісний склад місцевих рад у жодному разі не перевищує 200 осіб, тому встановлене обмеження не стосується заходів, які необхідні для забезпечення роботи органів місцевого самоврядування, зокрема, місцевих рад. Отже, у профільному законодавстві, яке спрямоване на подолання негативних наслідків пандемії, не передбачено підстав для призначення сільськими, селищними головами проведення закритих сесій рад.

Одним з прав членів територіальних громад і безпосереднім обов'язком сільського, селищного, міського голови $є$ звітування перед територіальною громадою не рідше одного разу на рік. У багатьох громадах відповідні звіти подавалися шляхом викладення у ЗМІ для загального доступу. 3 одного боку, це $\epsilon$ прямим порушенням вимоги ч. 7 ст. 42 Закону України «Про місцеве самоврядування в Україні», але 3 іншого - в умовах карантину $\epsilon$ недоцільним проведення масових заходів, а як рекомендацію можна запропонувати після закінчення особливого режиму повторно прозвітувати перед територіальною громадою 
на відкритій зустрічі з громадянами. Надалі можна було б врегулювати це питання шляхом внесення змін до закону.

Особливо актуальною залишається нині проблема забезпечення участі в місцевому самоврядуванні членів низки територіальних громад, розташованих у Донецькій та Луганській областях, у яких тривалий час не призначаються перші вибори місцевих рад. Вважаю, що позиція Центральної виборчої комісії щодо відмови у призначенні місцевих виборів у цих громадах $\epsilon$ юридично необгрунтованою та негативно впливає на соціально-економічний розвиток громад, не сприяє залученню жителів до місцевого самоврядування, не сприяє соціальній єдності громадян та гальмує проведення реформи децентралізації.

Багато питань виникає щодо доцільності та правової зумовленості створення військово-цивільних адміністрацій у населених пунктах, що наближені до лінії розмежування. Можна погодитись із тим, що створення військово-цивільних адміністрацій мало підстави у 2014-2015 роках, що детермінувалося нездатністю органів місцевого самоврядування виконувати свої повноваження та неможливістю проведення місцевих виборів. Разом із тим протягом наступних років ситуація набула значних змін, зокрема, більшість перешкод для призначення та проведення виборів втратили актуальність, значна частина територіальних громад перейшла у режим мирного життя. Тому фактичне позбавлення громадян права вибирати власні органи місцевого самоврядування $€$ порушенням їхніх конституційних прав на участь у місцевому самоврядуванні, адже, наприклад, неодноразові звернення Луганської та Донецької обласних державних адміністрацій до ЦВК щодо призначення перших виборів у Новоайдарській та Гірській об’єднаних територіальних громадах досі не знайшли вирішення у позитивний спосіб.

Особливістю правового регулювання інституту місцевих референдумів в Україні є застарілість і неповнота його норм, адже навіть Закон України «Про всеукраїнський та місцеві референдуми» 1991 р., який чітко не визначав шляхів імплементації рішень місцевих референдумів, 2012 р. втратив чинність у зв'язку 3 ухваленням Закону України «Про всеукраїнський референдум» [29]. Значно звуженим залишається і коло суб'єктів, що мають право участі у місцевому референдумі, оскільки відповідно до Конституції України таке право мають громадяни України, а тому ігноруються права постійних жителів, що не мають українського громадянства, 
хоча право на здійснення місцевого самоврядування мають усі члени територіальних громад.

Прийняття Закону України «Про всеукраїнський референдум» від 26.01.2021 р. після тривалих дискусій та правового вакууму у сфері прямого народовладдя значно актуалізувало питання щодо розробки та ухвалення закону про місцеві референдуми. Нині відбувається процес підбиття підсумків обговорення громадськістю проєкту Закону України «Про місцевий референдум» [39].

Місцевий референдум, згідно 3 проєктом, розглядається як спосіб самостійного вирішення територіальною громадою питань місцевого значення. Зокрема, на місцевому референдумі громадяни зможуть вирішувати питання висловлення недовіри місцевій владі, затвердження статуту територіальної громади або змін до нього, затвердження програми розвитку територіальної громади тощо. Таким чином, за межі інституту референдуму, згідно з проєктом, виведено області, райони та Автономну Республіку Крим, що викликає запитання про шляхи вирішення питань, які становлять спільні інтереси громад населенням цих територій шляхом безпосередньої демократії.

Проєкт визначає також обмеження предмета референдуму. Так, на місцевий референдум не можуть виноситися питання: 1) які $\epsilon$ предметом всеукраїнського референдуму; 2) які суперечать положенням Конституції і законів України (наприклад, щодо питань, спрямованих на ліквідацію незалежності України, порушення державного суверенітету і територіальної цілісності, створення загрози нацбезпеці, розпалювання міжетнічної, расової або релігійної ворожнечі тощо); 3) віднесені Конституцією та законами до компетенції інших органів влади, зокрема, з приводу делегованих органам місцевого самоврядування повноважень.

Серед дискусійних новацій проєкту привертає увагу можливість винесення на місцевий референдум питання про висловлення недовіри місцевій раді та (або) сільському, селищному, міському голові, для ініціювання якого буде досить підтвердження згоди щонайменше $10 \%$ мешканців територіальної громади. Вважаю, що така норма створює певні ризики для міських голів, які за умов дії мажоритарної виборчої системи абсолютної більшості здобули перемогу у другому турі виборів, а також депутатам місцевих рад, що вибрані за списками політичних партій. За умов значної політизації виборчого процесу на місцевому рівні публічної влади цим можуть скористатися різні 
політичні сили як на місцевому, так і на загальнонаціональному рівнях для зміни результатів місцевих виборів. Сучасний рівень розвитку інформаційних технологій, без сумніву, дозволяє зібрати передбачену законом кількість голосів мешканців територіальної громади та згодом на місцевому референдумі оголосити недовіру місцевій владі. Не виключена й інша потенційно конфліктна ситуація, коли «сильна» і впливова місцева влада ініціює місцевий референдум з метою посилення своїх позицій перед центральною владою, зокрема, через затвердження на місцевому референдумі програми розвитку територіальної громади або змін, які б вплинули на центральну владу через необхідність відреагувати на запит громади, закріплений рішенням місцевого референдуму.

$€$ певні суперечності щодо вирішення на місцевому референдумі питань місцевого значення. Так, п. 5 ч. 1 ст. 3 проєкту відносить до предмета референдуму «інше питання місцевого значення, віднесене Конституцією та законами України до відання територіальної громади, iї органів та посадових осіб». Разом із тим ч. 2. ст. 3 визначає, що питання щодо реалізації повноважень органів місцевого самоврядування, їх посадових осіб із прийняття нових нормативно-правових актів, внесення до них змін (крім визнання такими, що втратили чинність, актів, окремих їх положень); внесення змін, скасування актів індивідуальної дії органів місцевого самоврядування; реалізації повноважень органів місцевого самоврядування, їх посадових осіб із прийняття актів індивідуальної дії, внесення до них змін, їх скасування такими, що не можуть бути предметом референдуму. Виникає закономірне запитання: чи можуть реалізовувати повноваження органи і посадові особи місцевого самоврядування шляхом видання нормативно-правових актів? Якщо так, то як тоді співвіднести суперечливі норми проєкту.

Нечітко визначено в проєкті юридичні наслідки місцевого референдуму. Ст. 4 проголошує, що «рішення, прийняте на місцевому референдумі, $\epsilon$ обов'язковим для виконання на відповідній території», але з деяких інших положень проєкту закону не завжди випливає імперативність вказаного положення. Так, ст. 111 передбачає, що посадові особи та органи місцевого самоврядування, до повноважень яких належить вирішення питання, що виносилося на місцевий референдум, зобов'язані розглянути результати місцевого референдуму та врахувати їх у разі прийняття рішення з відповідного питання. Тобто йдеться 
більше про консультативний характер референдуму, а не про імперативний. При цьому в проєкті не закріплено визначення та розмежування місцевих референдумів за юридичними наслідками, що могло б сприяти більш чіткому врегулюванню результатів референдуму за різними питаннями. Як варіант можна запропонувати визначення у проєкті видів місцевого референдуму за юридичними наслідками, а також зміну місцевого референдуму з імперативного на консультативний, якщо у голосуванні взяли участь менше $50 \%$ виборців у територіальній громаді.

Неузгоджений характер має також і регулювання порядку організації і проведення референдумів щодо питань, які вже виносилися на референдум. Так, згідно з ч. 2 ст. 4 рішення, прийняте на місцевому референдумі за ініціативою громади, може бути змінене виключно шляхом місцевого референдуму не раніше ніж через три роки $з$ дня його ухвалення, тоді як згідно з ч. 2 ст. 113 питання місцевого референдуму про втрату чинності нормативно-правовим актом органу місцевого самоврядування або його окремими положеннями, не підтримане виборцями на місцевому референдумі за ініціативою громади, може бути повторно винесене на місцевий референдум за ініціативою громади не раніше як через рік з дня офіційного оголошення результатів місцевого референдуму за ініціативою громади.

Для вдосконалення інституту місцевого референдуму необхідно: по-перше, передбачити право бути суб'єктом місцевого референдуму громадським організаціям та партійним організаціям; по-друге, закріпити однакові умови як для прибічників питання, що виноситься на референдум, так і щодо їхніх опонентів (рівні норми доступу до ефірного часу, розташування інформації в друкованих та інших 3MI тощо); по-третє, надати можливість проведення на рівні населених пунктів консультативних референдумів з визначених законом питань, які не належать до компетенції територіальних громад, однак стосуються їх інтересів (наприклад, зміни меж відповідного населеного пункту, його перейменування); почетверте, спростити умови ініціювання місцевого референдуму на вимогу членів громад шляхом скасування стадії скликання загальних зборів громадян з ініціювання місцевого референдуму; по-п'яте, визнати членів територіальної громади суб'єктами ініціювання консультативного місцевого референдуму тощо. 
Незважаючи на розглянуті недоліки проєкту, слід підтримати намагання органів влади нарешті забезпечити реалізацію конституційного права на участь у місцевих референдумах, які, за визначенням, $\epsilon$ необхідною, а в перспективі можуть стати ефективною формою прямої демократії.

Щодо передбаченого в межах карантину обмеження проведення масових заходів слід наголосити, що свобода мирних зборів не належить до абсолютних прав і може бути обмежена винятково «з метою запобігання заворушенням чи злочинам, для охорони здоров'я населення або захисту прав і свобод інших людей» (ч. 2 ст. 39 Конституції). Порядок проведення загальних зборів громадян за місцем проживання, згідно зі ст. 8 Закону України «Про місцеве самоврядування в Україні», визначається законом та статутом територіальної громади [36]. Разом із тим єдиним спеціальним нормативно-правовим актом у цій сфері залишається Постанова Верховної Ради України «Про затвердження Положення про загальні збори громадян за місцем проживання в Україні» від 17.12.1993 року [33], тоді як відповідно до ст. 146 Конституції України питання організації місцевого самоврядування, формування, діяльності та відповідальності органів місцевого самоврядування мають визначатися законом [18]. 3 огляду на зазначений конституційний припис, урегулювання проведення загальних зборів мешканців територіальних громад Постановою Верховної Ради України виявляється недостатнім. Крім того, аналіз норм Положення свідчить про його невідповідність сучасним потребам суспільства та стратегічним орієнтирам державної політики сприяння розвитку місцевого самоврядування та громадянського суспільства.

Практика застосування наявного правового масиву законодавства у сфері регулювання загальних зборів виявила низку перепон та складнощів, які перешкоджають належній реалізації цього складника права членів територіальних громад на участь у місцевому самоврядуванні: по-перше, позбавлення громадян (наприклад, внутрішньо переміщених осіб та осіб без зареєстрованого місця проживання на території громади) можливості ініціювання та участі у загальних зборах через формальну неналежність до територіальної громади; по-друге, до процесу вирішення питань на загальних зборах допускаються лише повнолітні члени територіальних громад, тоді як практика багатьох країн-членів ЄС стимулює залучення молоді до вирішення місцевих питань. Тому доцільно закріпити у статутах 
територіальних громад можливість участі осіб, молодших за 18 років, у загальних зборах із правом дорадчого голосу та виступу. Позитивна практика в цьому аспекті також $є$ (наприклад, Решетилівська ОТГ Полтавської області та Музиківська ОТГ Херсонської області); по третє, наділення виключно представників влади правом скликати збори на території внутрішніх населених пунктів, які не $\epsilon$ центром ОТГ, що позбавляє жителів права бути суб'єктом скликання загальних зборів за місцем проживання [11].

Важливим механізмом в умовах карантину виявилися електронні петиції (е-петиції) до органів місцевого самоврядування. Особливістю цього інституту $\epsilon$ можливість його використання не тільки громадянами України, але й іноземцями, причому законом не вимагається приналежність до відповідної територіальної громади, що логічно виправдано 3 огляду на екстериторіальність е-петицій як інструменту локальної демократії. Запровадження в Україні практики електронних петицій розпочалося у 2009 р., коли Україна, як і інші держави, що є учасниками Ради Європи, отримала Рекомендації Комітету Міністрів Ради Європи державам-учасникам 3 електронної демократії, у яких передбачалася необхідність запровадження системи електронних петицій як важливого механізму співпраці влади та суспільства. Із внесенням 2 липня 2015 р. змін до ст. 5 Закону України «Про звернення громадян» було встановлено, що особливою формою колективного звернення громадян до Президента, Верховної Ради, Кабінету Міністрів та органів місцевого самоврядування $€$ електронна петиція та доповнено II Розділ Закону ст. 23-1, якою регламентовано порядок подання та розгляду електронних петицій.

На сучасному етапі громадяни можуть подати е-петиції на офіційних вебсайтах органів місцевого самоврядування та через онлайн-платформи: «Єдина система місцевих петицій» (152 громади), Розумне місто (101 громада), вебсайти об'єднаних громад України (247 громад), Мій Голос (до будь-якого органу влади чи органу місцевого самоврядування), всього більше 500 громад [44]. Запровадження нових інформаційний технологій для подання петиції створило нову форму участі громадян у прийнятті управлінських рішень на рівні органів місцевого самоврядування i виявилося досить корисним в умовах запровадження карантинних заходів в Україні. Електронні петиції на місцевому рівні сприяють організації незалежних громадських 
ініціатив (громадські слухання, місцеві кампанії з лобіювання тощо) для винесення питань, які стосуються нагальних проблем, на порядок денний органів місцевого самоврядування. Електронні петиції до органів місцевого самоврядування, як правило, вимагають нижчий поріг підписів і дозволяють громаді легше донести свою думку. Але, попри те, що органи місцевого самоврядування відповідно до Закону України «Про звернення громадян» мають право самостійно встановлювати строки та необхідну кількість голосів для того, аби петицію було розглянуто в межах рекомендованих норм мінімальної кількості голосів, необхідної для розгляду петиції, відповідно до кількості жителів населеного пункту, подеколи органи місцевого самоврядування не дотримуються цих рекомендацій. Наприклад, у Житомирі для того, аби петиція була розглянута, вона має набрати 250 голосів упродовж 90 днів. У Полтаві для проведення аналогічної процедури виділяється 60 днів, у Херсоні і Черкасах - по 30 днів, і 20 днів в Ужгороді. Всі ці міста мають приблизно однакову кількість населення, у Одесі або Дніпрі треба зібрати 1000 підписів впродовж 90 днів, а в Києві за ті ж 90 днів - 10000 . Показовим у цьому плані $\epsilon$ досвід Вінниці та Луцька, де під збір підписів на підтримку петицій відводиться всього 14 днів. Хоч разом із тим зменшується і кількість необхідних підписів: 300 у Вінниці та 350 у Луцьку.

Дискусійним $€$ віднесення петицій до інститутів прямої демократії, адже насамперед «петиції дозволяють громадянам безпосередньо долучитися до процесу розробки й ухвалення рішень, проте вони ніде й ніколи не мають обов'язкової сили для тих органів влади, яким адресовані. Тобто громадяни в цьому разі жодних рішень не приймають, і останнє слово - завжди за вибраними представниками або ж посадовцями. Тому петиції $\epsilon$ швидше формою участі громадян у прийнятті рішень та способом комунікації суспільства і влади в рамках саме представницької моделі демократії [16].

Для підвищення ефективності е-петицій як форми участі громадян у сфері прийняття рішень органів публічної влади в Україні необхідно зменшити кількість голосів, яка встановлена для їх розгляду, а також розширити мережу електронних платформ органів публічної влади та органів місцевого самоврядування. Аби електронні петиції набули статусу дієвого механізму вирішення місцевих питань, необхідно врахувати особливості конкретної територіальної громади, визначити рівень 
активності громадян для того, щоб запровадити розумні межі та норми необхідної кількості підписів та часу на їх збір, адже встановлення надмірних часових меж призводить до втрати актуальності відповідного питання та марнує сили та кошти, які затрачені з боку ініціаторів петиції.

Новим механізмом у реалізації права на участь у місцевому самоврядуванні повинні стати консультації із громадськістю та бюджети участі, які поки що, на жаль, не врегульовані на рівні законодавства. Але практика органів місцевого самоврядування має свободу дій щодо того, кого наділяти чи не наділяти правом використання цих механізмів. На практиці все, як правило, зводиться або до жителів, або до членів територіальної громади. Участь у консультативно-дорадчих органах (далі - КДО) так само формально не пов'язана з місцем проживання та й, власне, не повинна мати такої «прив'язки» з огляду на природу і функції цих органів. Більш того, органи місцевого самоврядування можуть самостійно визначати порядок формування КДО, оскільки це питання законом також не регулюється, що може стати предметом подальших досліджень.

\section{Висновки}

Право на участь у місцевому самоврядуванні $\epsilon$ комплексним інститутом, який складається 3 права територіальної громади на місцеве самоврядування, права членів громади на участь у здійсненні місцевого самоврядування у формах прямої та представницької демократії, права органів місцевого самоврядування діяти у передбачений законом спосіб в інтересах територіальної громади та кожного громадянина - члена територіальної громади.

Реалізація права на участь у місцевому самоврядуванні в умовах спеціальних правових режимів потребує здійснення заходів нормативно-правового та організаційного характеру: 1) розширення використання дистанційних форм взаємодії суб'єктів місцевого самоврядування (наприклад, дистанційне ініціювання загальних зборів, дистанційні форми роботи представницьких та виконавчих органів місцевого самоврядування); 2) запровадження конференцій жителів, на відміну від загальних зборів, що сприятиме дотриманню карантинних вимог; 3) зменшення впливу посадових осіб місцевого самоврядування на процес реєстрації супровідних документів і проведення громадських заходів; 4) закріплення зобов'язання органів і посадових осіб місцевого самоврядування 
враховувати у своїй діяльності пропозиції, що були розроблені безпосередньо громадянами.

Вдосконалення інституту місцевого референдуму потребує: 1) закріплення права бути суб'єктами місцевого референдуму громадським та місцевим партійним організаціям; 2) закріплення однакових умов для прибічників та опонентів щодо питання, яке виноситься на референдум; 3) надання можливості проведення на рівні населених пунктів консультативних референдумів з визначених законом питань, які не належать до компетенції територіальних громад, однак стосуються їх інтересів; 4) спрощення умов ініціювання місцевого референдуму на вимогу членів громад шляхом скасування стадії скликання загальних зборів громадян 3 ініціювання місцевого референдуму; 5) визнання членів територіальної громади суб'єктами ініціювання консультативного місцевого референдуму тощо.

\section{Список використаних джерел:}

1. Ako J.N. A study of community and citizen participation in development and policymaking in Stockholm, Värmdo and Bortkyrka municipalities in Sweden. Malmö : Malmö University, 2017. 50 p. URL: http://muep.mau.se/bitstream/handle/2043/24434/Ndip-JADP18.pdf?sequence=1.

2. Абрам'юк I. Демократія участі: механізми громадської участі на місцевому, регіональному та національному рівнях : матеріали до курсу № 7 баз. навч. канд. на участь у Всеукр. мережі фахівців та практиків 3 регіон. і місц. розвитку. Київ, 2014. 50 с. URL: http://regionet.org.ua/files/.

3. Бальцій Ю.Ю.Право громадян на участь у місцевому самоврядуванні: поняття та зміст. Вісник Маріупольського державного університету. Серія: Право. 2011. Вип. 1. С. 65-70. URL: http://nbuv.gov.ua/UJRN/Vmdu_pr_2011_1_11.

4. Барометр свободи слова за грудень 2020 року. URL: https://imi.org.ua/monitorings/barometr-svobody-slova-zagruden-2020-roku-i37065

5. Батанов О.В. Муніципальна влада в Україні: конституційноправові проблеми організації та функціонування : дис. ... д-ра юрид. наук : 12.00.02. Київ, 2011. 478 с.

6. Батанов О.В., Кравченко В.В., Приходько Х.В. Партисипативна демократія у системі місцевого самоврядування: проблеми законодавчого регулювання. Аспекти публічного управління. 2014. № 9/10. C. 12-28. 
7. Богів Я. Конституційні аспекти регламентування статусу територіальної громади як первинної одиниці у системі місцевого самоврядування. Вісник національного університету «Львівська політехніка». Серія: Юридичні науки. 2016. № 855. С. 329-335.

8. Бранниган и Макбрайд (Brannigan and Mcbride) против Соединенного Королевства: Судебное решение от 26 мая 1993 2. URL: https://hudoc.echr.coe.int/eng\#\{\%22itemid\%22:[\%22001$57819 \% 22]\}$.

9. Бурін О.М. Проблеми впровадження концепції локальної демократії в Україні. Державне управління: удосконалення та розвиток. 2014. № 9. С. 11-16.

10. Васильєва Н.В., Бойко О.П. Роль партисипативної демократії в побудові громадянського суспільства в Україні. Вісник Національної академії державного управління при Президентові України. 2015. № 2. С. 98-105.

11. Використання інструментів локальної демократії в умовах карантину (звіт). URL: https://www.vplyv.org.ua/archives/545.

12. Дело «Финогенов и другие против России» (Finogenov and Others v. Russia) Жалобы №№ 18299/03 и 27311/03) : Постановление Суда от 20 декабря 2011 г. URL: http://www.echr.ru/ documents/doc/70089494/70089494.htm.

13. Дементьев В.В. Институциональная теория в Украине: направления исследований, особенности, перспективы. URL: http://www.instud.org/index.php?id=4\&material=15.

14. Дзюпин М. Перший рік добровільного об'єднання громад: судова практика. Ліга. Блоги. 2016, 5 квіт. URL: http://blog.liga.net/ user/mdzyupyn/ artide/21728.aspx (дата звернення: 04.06.2019).

15. Казакова Л.О. Конституційне право на місцеве самоврядування серед інших прав та свобод людини і громадянина в Україні : автореф. дис. на здобуття наук. ступеня канд. юрид. наук (доктора філософії) : 12.00.02. Ужгород, 2018. 18 с.

16. Колесников О. Е-петиції у системі місцевої демократії: досвід обласних центрів України. URL: https://samoorg.com.ua/ wp-content/uploads/2017/02/ Petitsiyi_gotov-1.pdf.

17. Колесников О. Правовий статус жителів/членів територіальних громад в Україні: проблеми законодавчого регулювання: Аналітична записка / Колесников О., Калашнікова О. та ін. URL: https://drive.google.com/file/d/1rYegtpuMdoQUgZNSLzMLhullx5 Vo2_ww/view.

18. Конституція України від 28 червня 1996 року. Офіційний вісник України 2010. № 72/1. С. 15. 
19. Конституція Чеської Республіки з 16 грудня 1992 р. Конституції нових держав Європи та Азії / Упорядник С. Головатий. Київ : Українська правнича фундація, Право, 1996. С. $445-484$.

20. Коронавірус і робота місцевих рад: які українські міста заборонили громадянам приходити на ceciï. URL: https://www.prostir.ua/?news=koronavirus-i-robota-mistsevyh-radyaki-ukrajinski-mista-zaboronyly-hromadyanam-pryhodyty-na-sesiji.

21. Криворот В., Мартиненко А. Втручання в права людини під час пандемії. URL: https://yur-gazeta.com/publications/practice/ inshe/vtruchannya-v-prava-lyudini-pid-chas-pandemiyi.html.

22. Кримінальний кодекс України : Закон від 05.04.2001 № 2341-III. Відомості Верховної Ради України (ВВР). 2001. № 25-26. Ст. 131.

23. Любченко П.М. Проблеми реалізації права громадян на участь у місцевому самоврядуванні. Вісник Академії правових наук України. Харків, 2009. № 1. С. 124-133.

24. Лялюк О.Ю. Правове регулювання та практика імплементації законодавства з питань партисипативної демократії в європейських країнах. Державне будівництво та місцеве самоврядування. Харків, 2017. Вип. 33. С. 73-89.

25. Молчанова Ю.Ю. Муніципальне регулювання здійснення членами територіальної громади права на участь у місцевому самоврядуванні : дис ... канд. юрид. наук : 12.00.02. Харків, 2019. 236 c.

26. Москальчук К.М. Конституційне право доступу громадян до служби в органах місцевого самоврядування : дис ... канд. юрид. наук : 12.00.02. Одеса, 2013. 226 с.

27. Попова І.М. Організаційно-правові механізми забезпечення партисипативної демократії (демократії участі) у системі місцевого самоврядування. Теорія та практика державного управління $і$ місцевого самоврядування. 2016. № $1 . \quad$ URL: http://el-zbirn-du.at.ua/2016_1/20.pdf.

28. Про внесення змін до деяких законодавчих актів України, спрямованих на запобігання виникненню i поширенню коронавірусної хвороби (COVID-19) : Закон України від 17 березня 2020 року. URL: https://zakon.rada.gov.ua/laws/show/530-20\#Text.

29. Про всеукраїнський референдум : Закон України від 26.01.2021 № 1135-IX. URL: https://zakon.rada.gov.ua/laws/show/ 1135-20\#Text. 
30. Про гмінне самоврядування : Закон Республіки Польща від 8 березня 1990 p. URL: https://www.csi.org.ua/publications/ zakon-pro-gminne-samovryaduvannya-vid-8-b/.

31. Про доступ до публічної інформації : Закон України від 13 січня 2011 року № 2939-VI. Відомості Верховної Ради України. 2011. № 32. Ст. 314.

32. Про запобігання поширенню на території України гострої респіраторної хвороби COVID-19, спричиненої коронавірусом SARS-CoV-2 : Постанова Кабінету Міністрів України від 11.03.2020 № 211. URL: https://zakon.rada.gov.ua/laws/show/211-2020-\% D0\%BF\#Text.

33. Про затвердження Положення про загальні збори громадян за місцем проживання в Україні : Постанова Верховної Ради України від 17 грудня 1993 року № 3748-XII. Відомості Верховної Ради України. 1994. № 6. Ст. 30.

34. Про звернення громадян : Закон України від 2 жовтня 1996 p. URL: https://zakon.rada.gov.ua/laws/show/393/ 96-\%D0\%B2\%D1\%80\#Text.

35. Про інформацію : Закон України від 2 жовтня 1992 р. № 2657-XII. URL: http://www.rada.gov.ua.

36. Про місцеве самоврядування в Україні : Закон України від 21.05.1997 № 280/97-BP. URL: https://zakon.rada.gov.ua/laws/show/ 280/97-\%D0\%B2\%D1\%80.

37. Про органи самоорганізації населення : Закон України від 11.07.2001 № 2625-III. URL: https://zakon.rada.gov.ua/laws/ show/2625-14.

38. Про рішення Ради національної безпеки і оборони України від 13 березня 2020 року «Про невідкладні заходи щодо забезпечення національної безпеки в умовах спалаху гострої респіраторної хвороби COVID-19, спричиненої коронавірусом SARS-CoV-2» : Указ Президента України від 13.03.2020 № 87. URL: https://www.president.gov.ua/documents/872020-32741.

39. Проєкт Закону України «Про місцевий референдум». Проєкт виноситься на громадське обговорення. URL: https://www.rada.gov.ua/uploads/documents/ 66764.pdf.

40. Рішення Конституційного Суду України у справі за конституційним поданням 70 народних депутатів України щодо відповідності Конституції України (конституційності) положень частини першої статті 10, пункту 3 частини другої, частин п'ятої, шостої статті 11, 15, частини першої статті 17, статті 24, пункту 3 розділу VI «Заключні положення» Закону України «Про політичні 
партії в Україні» (справа про утворення політичних партій в Україні) від 12 червня 2007 року № 2-рп/2007. URL: https://zakon.rada.gov.ua/laws/show/v002p710-07\#Text.

41. Рішення Конституційного Суду України у справі за конституційним поданням 51 народного депутата України щодо відповідності Конституції України (конституційності) положень статті 92, пункту 6 розділу X «Перехідні положення» Земельного кодексу України (справа про постійне користування земельними ділянками) від 22 вересня 2005 року № 5-рп/2005. URL: https://zakon.rada.gov.ua/laws/show/v005p710-05\#Text.

42. Рішення Конституційного Суду України у справі за конституційним поданням Уповноваженого Верховної Ради України з прав людини щодо відповідності Конституції України (конституційності) окремих положень частини другої статті 8, другого речення частини четвертої статті 16 Закону України «Про звернення громадян» (справа про звернення осіб, визнаних судом недієздатними) від 11 жовтня 2018 року № 8-p/2018. URL: https://zakon.rada.gov.ua/laws/show/v008p710-18\#Text.

43. Ткачук П.А. Участь громадян України в місцевому самоврядуванні : автореф. дис. ... канд. юрид. наук : 12.00.02. Київ, 2003. 17 с.

44. Хуткий Д. Е-петиції в Україні: формування народного порядку денного. Аналітична записка. Київ. 2017. URL: http://www.fulbrightcircle.org.ua/wp-content/uploads/2017/12/ Dmytro_Khutkyy_E-petitions.pdf.

45. Чернега Р.Т. Право громадян на участь у місцевому самоврядуванні України: стан та шляхи вдосконалення : автореф. дис ... канд. юрид. наук : 12.00.02. Київ, 2007. 20 с.

46. Чернега Р.Т. Право громадян на участь у місцевому самоврядуванні України: стан та шляхи вдосконалення : дис ... канд. юрид. наук : 12.00.02. Київ, 2007. 211 с.

47. Чиркін А.С. Конституційні засади організації місцевого самоврядування в Чехії. Вісник Луганського державного університету внутрішніх справ імені Е.О. Дідоренка. 2014. Вип. 1. С. 73-82. URL: http://nbuv.gov.ua/UJRN/Vlduvs_2014_1_11.

48. Шевченко А.О. Муніципально-правовий статус територіальної громади в Україні та зарубіжних державах : дис. ... канд. юрид. наук (доктора філософії) : 12 00.02. Київ. 2020. 216 с.

49. Шугрина Е.С. Гарантии права на осуществление местного самоуправления : автореф. дис. ... док. юрид. наук : 12.00.02. Москва, 2008. 57 с. 